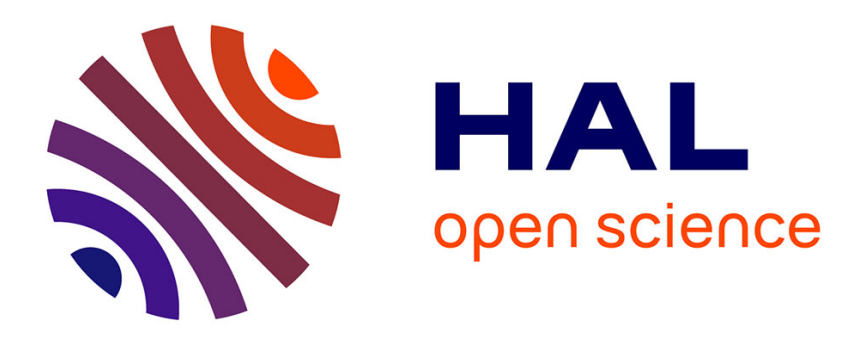

\title{
Carbonic anhydrase binding site parameterization in OPLS-AA force field.
}

\author{
Guillaume Bernadat, Claudiu T Supuran, Bogdan I Iorga
}

\section{To cite this version:}

Guillaume Bernadat, Claudiu T Supuran, Bogdan I Iorga. Carbonic anhydrase binding site parameterization in OPLS-AA force field.. Bioorganic and Medicinal Chemistry, 2013, 21 (6), pp.1427-1430. 10.1016/j.bmc.2012.10.040 . hal-00798418

\section{HAL Id: hal-00798418 https://hal.science/hal-00798418}

Submitted on 16 Mar 2021

HAL is a multi-disciplinary open access archive for the deposit and dissemination of scientific research documents, whether they are published or not. The documents may come from teaching and research institutions in France or abroad, or from public or private research centers.
L'archive ouverte pluridisciplinaire HAL, est destinée au dépôt et à la diffusion de documents scientifiques de niveau recherche, publiés ou non, émanant des établissements d'enseignement et de recherche français ou étrangers, des laboratoires publics ou privés. 


\title{
Carbonic anhydrase binding site parameterization in OPLS-AA force field
}

\author{
Guillaume Bernadat, ${ }^{\mathrm{a}, 1}$ Claudiu T. Supuran ${ }^{\mathrm{b}}$ and Bogdan I. Iorga ${ }^{\mathrm{a}, *}$ \\ ${ }^{a}$ Institut de Chimie des Substances Naturelles, CNRS UPR 2301, Labex LERMIT, Centre de Recherche de Gif, 1 Avenue de la \\ Terrasse, F-91198 Gif-sur-Yvette, France \\ ${ }^{\text {b }}$ Dipartimento di Chimica, Laboratorio di Chimica Bioinorganica, Università degli Studi di Firenze, Rm 188, Via della \\ Lastruccia 3, Polo Scientifico, I-50019 Sesto Fiorentino (Firenze), Italy
}

\begin{abstract}
The parameterization of carbonic anhydrase binding site in OPLS-AA force field was performed using quantum chemistry calculations. Both $\mathrm{OH} 2$ and $\mathrm{OH}-$ forms of the binding site were considered, showing important differences in terms of atomic partial charges. Three different parameterization protocols were used, and the results obtained highlighted the importance of including an extended binding site in the charge calculation. The force field parameters were subsequently validated using standard molecular dynamics simulations. The results presented in this work should greatly facilitate the use of molecular dynamics simulations for studying the carbonic anhydrase, and more generally, the metallo-enzymes.
\end{abstract}

\section{Keywords}

Carbonic anhydrase ; Molecular dynamics ; Force field parameterization ; OPLS-AA force field ; Quantum chemistry

\section{Introduction}

Carbonic anhydrase (CA, EC 4.2.1.1) is a widespread enzyme in all organisms, which catalyzes the hydration of $\mathrm{CO}_{2}$ to bicarbonate and protons. (Scheme 1). Carbonic anhydrase inhibitors are available or in advanced stages of development for the treatment of various diseases e.g. glaucoma and ocular hypertension,,,$\underline{1,}$ cancer,$\underline{3-7}$ obesity,,$\underline{8}$ epilepsy, $\underline{10}$ etc. Possible applications of carbonic anhydrase activators in Alzheimer's disease and other memory therapies are also currently under evaluation. $\frac{11}{}$ All these data evidence the importance of this enzyme, for mechanistic studies or drug design of selective inhibitors or activators. 


\section{$\mathrm{CO}_{2}+\mathrm{H}_{2} \mathrm{O} \rightleftharpoons \mathrm{HCO}_{3}^{-}+\mathrm{H}^{+}$}

Scheme 1. Chemical reaction catalyzed by carbonic anhydrase.

Molecular dynamics studies of metallo-enzymes in general, and of carbonic anhydrase in particular, were hampered by the lack of appropriate force field parameters within the commonly used software. These difficulties were overcome over the years, but presently the molecular modeling of carbonic anhydrase is somewhat underdeveloped compared to the explosive development that the carbonic anhydrase field has known during the last decades. $\underline{12-16}$

A number of force fields were used in the past for studies involving molecular dynamics simulations of carbonic anhydrase: GROMOS, $\underline{17-19}$ CHARMM $\stackrel{20-24}{\underline{C}}$ and AMBER. $\frac{25-35}{}$ A specific Zn AMBER force field was recently developed, $\frac{36}{6}$ with direct applications for the carbonic anhydrase. The same force fields were used in the context of QM/MM studies,,$\underline{24,37-39}$ to take into account the formation and breaking of bonds during the enzymatic reaction. A general review of molecular dynamics simulations of metallo-proteins is also available. $\underline{40}$

A notable force field missing from the list presented above is OPLS-AA. $\underline{41}, \underline{42}$ This force field was developed with a strong emphasis on reproducing condensed-phase properties of model compounds, is currently implemented in most of the commonly used molecular dynamics software packages and has been recently shown to give particularly good results in free energy calculations. $\frac{43-46}{}$ In these conditions, we decided to undertake the parameterization of CA binding site in the OPLS-AA force field and this paper describes the procedure that we followed, along with the topologies and parameters required to perform molecular dynamics simulations using Gromacs software. $\underline{47}$

\section{Results and discussion}

The procedure used in this work involves three steps: i) charge calculation using quantum methods, ii) generation of bonding parameters, and iii) validation of these force field parameters using molecular dynamics simulations. 
For the charge calculations, the neutron structure of carbonic anhydrase II (PDB code $3 \mathrm{KKX})^{\underline{48}}$ was used. The choice of this structure was prompted by three criteria: the high quality of the atomic coordinates, the presence of the representative water molecules in the binding site and the unambiguous assignment of the protonation states for all residues. Two different representations of the binding site were considered: i) a minimal binding site (Figure 1), containing the side chains of three histidine residues (His94, His96 and His119), the zinc ion and the zinc-bound water molecule (either $\mathrm{OH}_{2}$ or $\mathrm{OH}^{-}$forms) and ii) an extended binding site (Figure 2), containing the residues from the minimal binding site and the neighbors of the zincbound water (the side chain of Thr199 and the DW and W1 water molecules). The charge calculation was performed with or without geometry optimization, and three different protocols can be distinguished:

Protocol A: minimal binding site, with geometry optimization, CHelpG charge calculation, two-stage RESP charge fitting.

Protocol B: minimal binding site, without geometry optimization, CHelpG charge calculation, two-stage RESP charge fitting.

Protocol C: extended binding site, without geometry optimization, CHelpG charge calculation, two-stage RESP charge fitting.

For each protocol and for the two forms of the binding site $\left(\mathrm{OH}_{2}\right.$ or $\left.\mathrm{OH}^{-}\right)$, the charge calculation (and in the case of Protocol A, the geometry optimization) was performed with three different methods (HF, B3LYP and MP2) with either the $6-31 \mathrm{G}(\mathrm{d})$ or $6-311++\mathrm{G}(2 \mathrm{~d}, \mathrm{p})$ basis sets. Whereas the first basis set is generally used for charge calculations and force field parameterization of simple organic molecules, the second one is probably necessary for a better description of the zinc ion influence within this system. The charges were calculated for all binding site atoms, including the imidazole rings of His94, His96 and His 119. The results for selected, representative atoms are presented in Tables 1 and 2, where the calculated charges are compared with those already present in the OPLS-AA force field for the same residues (see the Supplementary Data file for the complete charge data set).

The analysis of the results from Table $1\left(\mathrm{OH}_{2}\right.$ form of the binding site) shows that i) the geometry optimization (comparison of protocols A and B) has very little influence on the charges of the zinc ion and zinc-bound water, ii) the inclusion of the second sphere of coordination in the charge calculation (extended 
binding site, comparison of protocols B and C) leads to sensibly different charges, especially for the zincbound water, iii) the use of the $6-311++G(2 d, p)$ basis set provides smaller absolute values for all charges and thus a smoother polarization of the binding site, iv) the B3LYP method provides significantly lower absolute values for the charges compared with HF and MP2, but this behavior is probably due to a methodspecific artifact $\frac{49}{9}$ and v) very important differences are observed between the calculated charges and the OPLS-AA native charges for the same residues. Considering all these elements, the charges calculated at the $\mathrm{HF} / 6-311++\mathrm{G}(2 \mathrm{~d}, \mathrm{p})$ level with the protocol $\mathrm{C}$ were selected as representative for this system (line highlighted in red in Table 1).

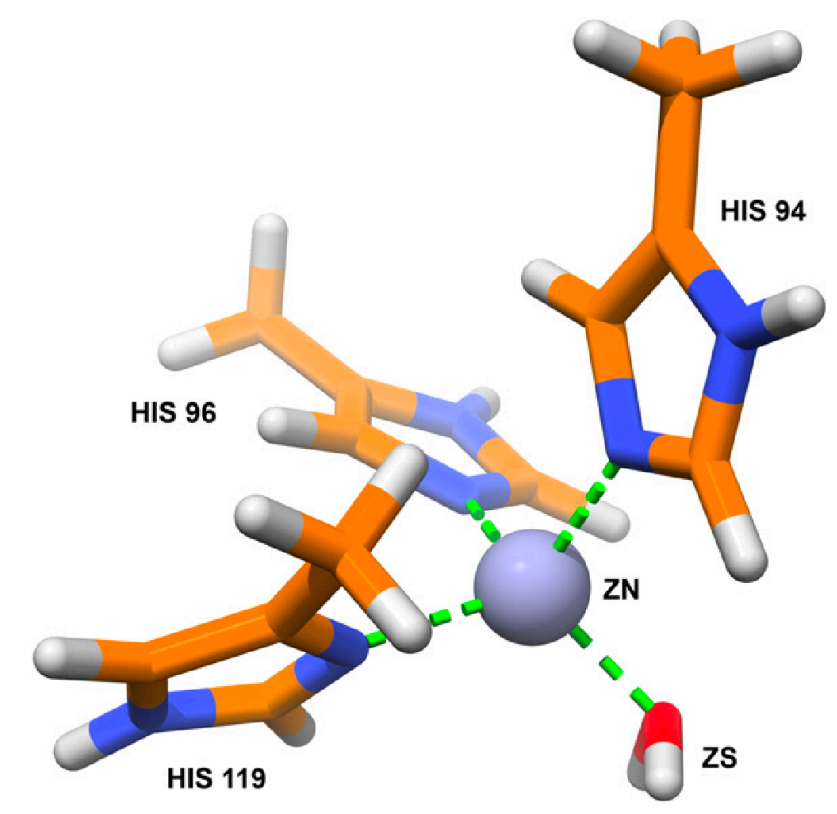

Figure 1. Minimal representation of the carbonic anhydrase binding site $\left(\mathrm{OH}_{2}\right.$ form), containing the zinc ion, side chains of three histidine residues (His94, His96 and His119) and zinc-bound water.

Table 1. QM charges calculated with different protocols and methods for the $\mathrm{OH}_{2}$ form of carbonic anhydrase binding site.

\begin{tabular}{|c|c|c|c|c|c|c|c|c|c|c|}
\hline Protocol & Method & $\begin{array}{l}\text { HIS } \\
\text { (ND) }\end{array}$ & 94 & $\begin{array}{l}\text { HIS } \\
\text { (ND) }\end{array}$ & 96 & $\begin{array}{ll}\text { HIS } & 119 \\
& \\
\text { (NE) } & \end{array}$ & $\mathbf{Z N}$ & ZS (O) & $\begin{array}{l}\text { ZS } \\
\text { (H1) }\end{array}$ & $\begin{array}{l}\mathrm{ZS} \\
\text { (H2) }\end{array}$ \\
\hline A & $\mathrm{HF} / 6-31 \mathrm{G}(\mathrm{d})$ & -0.291 & & -0.291 & & -0.285 & 0.745 & -0.762 & 0.459 & 0.459 \\
\hline A & $\mathrm{HF} / 6-311++\mathrm{g}(2 \mathrm{~d}, \mathrm{p})$ & -0.236 & & -0.236 & & -0.216 & 0.676 & -0.715 & 0.433 & 0.433 \\
\hline A & B3LYP/6-31G(d) & -0.197 & & -0.197 & & -0.164 & 0.533 & -0.670 & 0.432 & 0.432 \\
\hline
\end{tabular}




\begin{tabular}{|c|c|c|c|c|c|c|c|c|}
\hline \multirow{2}{*}{ A } & \multicolumn{8}{|l|}{ B3LYP/6- } \\
\hline & $311++\mathrm{g}(2 \mathrm{~d}, \mathrm{p})$ & -0.162 & -0.162 & -0.120 & 0.487 & -0.640 & 0.406 & 0.406 \\
\hline A & $\mathrm{MP} 2 / 6-31 \mathrm{G}(\mathrm{d})$ & -0.259 & -0.259 & -0.246 & 0.691 & -0.750 & 0.456 & 0.456 \\
\hline $\mathrm{B}$ & $\mathrm{HF} / 6-31 \mathrm{G}(\mathrm{d})$ & -0.183 & -0.183 & -0.415 & 0.745 & -0.784 & 0.483 & 0.483 \\
\hline B & $\mathrm{HF} / 6-311++\mathrm{g}(2 \mathrm{~d}, \mathrm{p})$ & -0.111 & -0.111 & -0.357 & 0.651 & -0.703 & 0.453 & 0.453 \\
\hline B & B3LYP/6-31G(d) & -0.120 & -0.120 & -0.345 & 0.565 & -0.691 & 0.460 & 0.460 \\
\hline \multirow[t]{2}{*}{ B } & \multicolumn{8}{|l|}{ B3LYP/6- } \\
\hline & $311++\mathrm{g}(2 \mathrm{~d}, \mathrm{p})$ & -0.065 & -0.065 & -0.306 & 0.490 & -0.626 & 0.432 & 0.432 \\
\hline B & $\mathrm{MP} 2 / 6-31 \mathrm{G}(\mathrm{d})$ & -0.183 & -0.183 & -0.415 & 0.745 & -0.784 & 0.483 & 0.483 \\
\hline $\mathrm{C}$ & $\mathrm{HF} / 6-31 \mathrm{G}(\mathrm{d})$ & -0.208 & -0.208 & -0.407 & 0.802 & -0.925 & 0.480 & 0.480 \\
\hline $\mathbf{C}$ & $\mathrm{HF} / 6-311++\mathrm{g}(2 \mathrm{~d}, \mathrm{p})$ & -0.123 & -0.123 & -0.326 & 0.691 & -0.868 & 0.454 & 0.454 \\
\hline $\mathrm{C}$ & B3LYP/6-31G(d) & -0.159 & -0.159 & -0.341 & 0.632 & -0.877 & 0.464 & 0.464 \\
\hline \multirow[t]{2}{*}{$\mathrm{C}$} & \multicolumn{8}{|l|}{ B3LYP/6- } \\
\hline & $311++\mathrm{g}(2 \mathrm{~d}, \mathrm{p})$ & -0.090 & -0.090 & -0.286 & 0.551 & -0.831 & 0.441 & 0.441 \\
\hline $\mathrm{C}$ & $\mathrm{MP} 2 / 6-31 \mathrm{G}(\mathrm{d})$ & -0.208 & -0.208 & -0.407 & 0.802 & -0.925 & 0.480 & 0.480 \\
\hline- & OPLS-AA ${ }^{\mathrm{a}}$ & -0.564 & -0.564 & -0.564 & 2.000 & -1.040 & 0.520 & 0.520 \\
\hline
\end{tabular}

${ }^{a}$ Generic OPLS-AA charges as implemented in Gromacs ${ }^{47}$

Similarly, the analysis of the results from Table $2\left(\mathrm{OH}^{-}\right.$form of the binding site $)$shows analogous trends, and the charges calculated at the HF/6-311++G(2d,p) level with the protocol C were also selected in this case as representative for the carbonic anhydrase binding site (line highlighted in red in Table 2). 


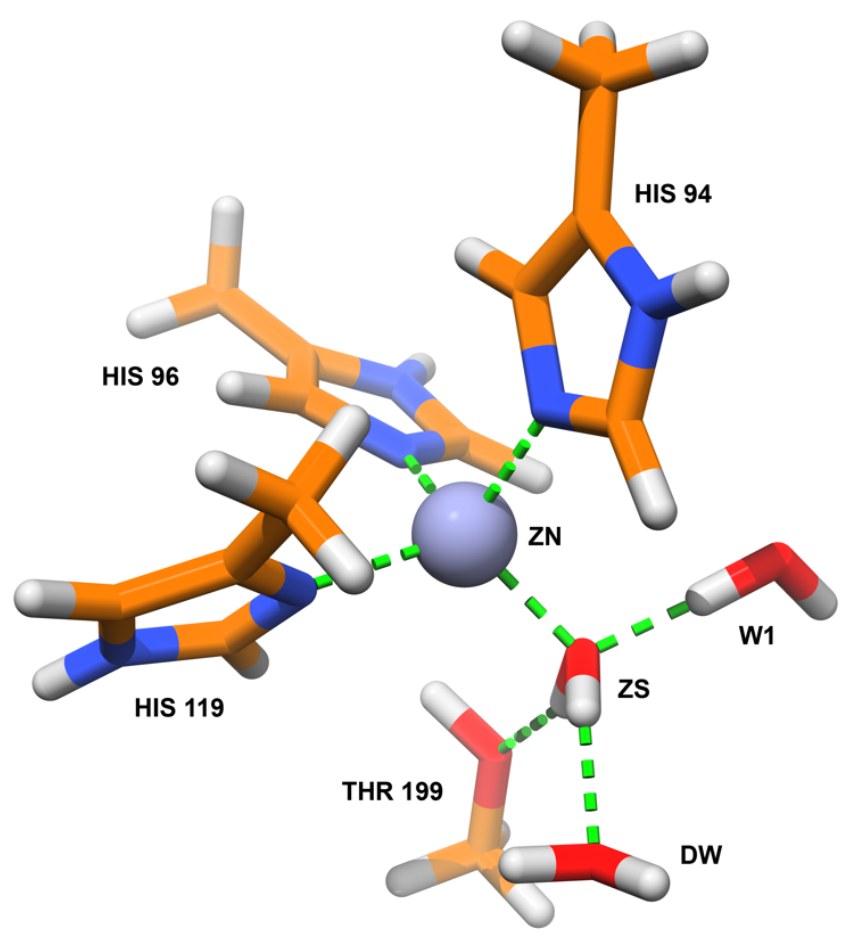

Figure 2. Extended representation of the carbonic anhydrase binding site $\left(\mathrm{OH}_{2}\right.$ form), containing the zinc ion, side chains of three histidine residues (His94, His96 and His119), zinc-bound water and the residues interacting with the latter: side chain of Thr199 residue and DW and W1 waters.

Table 2. QM charges calculated with different protocols and methods for the $\mathrm{OH}^{-}$form of carbonic anhydrase binding site.

\begin{tabular}{llllllllll}
\hline Protocol & Method & HIS 94 (ND) & HIS 96 (ND) & HIS & $\mathbf{1 1 9}$ & ZN & ZS (O) & ZS (H1) & ZS (H2) \\
& & & & (NE) & & & & & \\
\hline A & HF/6-31G(d) & -0.162 & -0.162 & -0.328 & 0.624 & -0.916 & 0.374 & - \\
A & HF/6-311++g(2d,p) & -0.105 & -0.105 & -0.291 & 0.600 & -0.902 & 0.351 & - \\
A & B3LYP/6-31G(d) & -0.079 & -0.079 & -0.243 & 0.407 & -0.762 & 0.336 & - \\
A & B3LYP/6- & & & & & & & & \\
& 311++g(2d,p) & -0.053 & -0.053 & -0.237 & 0.426 & -0.798 & 0.331 & - \\
A & MP2/6-31G(d) & -0.165 & -0.165 & -0.323 & 0.613 & -0.888 & 0.356 & - \\
\hline B & HF/6-31G(d) & -0.088 & -0.088 & -0.243 & 0.576 & -0.973 & 0.361 & - \\
B & HF/6-311++g(2d,p) & -0.041 & -0.041 & -0.189 & 0.566 & -0.948 & 0.327 & - \\
B & B3LYP/6-31G(d) & -0.017 & -0.017 & -0.169 & 0.346 & -0.828 & 0.340 & -
\end{tabular}




\begin{tabular}{lllllllll} 
& $311++\mathrm{g}(2 \mathrm{~d}, \mathrm{p})$ & 0.003 & 0.003 & -0.144 & 0.388 & -0.836 & 0.306 & - \\
$\mathrm{B}$ & $\mathrm{MP} 2 / 6-31 \mathrm{G}(\mathrm{d})$ & -0.088 & -0.088 & -0.243 & 0.576 & -0.973 & 0.361 & - \\
\hline $\mathrm{C}$ & $\mathrm{HF} / 6-31 \mathrm{G}(\mathrm{d})$ & 0.047 & 0.047 & -0.228 & 0.430 & -0.849 & 0.304 & - \\
$\mathrm{C}$ & HF/6-311++g(2d,p) & $\mathbf{0 . 1 1 4}$ & $\mathbf{0 . 1 1 4}$ & $\mathbf{- 0 . 1 5 2}$ & $\mathbf{0 . 3 7 6}$ & $\mathbf{- 0 . 7 7 8}$ & $\mathbf{0 . 2 4 0}$ & - \\
$\mathrm{C}$ & B3LYP/6-31G(d) & 0.097 & 0.097 & -0.160 & 0.230 & -0.716 & 0.275 & - \\
$\mathrm{C}$ & B3LYP/6- & & & & & & & \\
& 311++g(2d,p) & 0.148 & 0.148 & -0.113 & 0.214 & -0.670 & 0.220 & - \\
$\mathrm{C}$ & MP2/6-31G(d) & 0.047 & 0.047 & -0.228 & 0.430 & -0.849 & 0.304 & - \\
\hline- & $\mathbf{O P L S - A A}$ & $\mathbf{- 0 . 5 6 4}$ & $\mathbf{- 0 . 5 6 4}$ & $\mathbf{- 0 . 5 6 4}$ & $\mathbf{2 . 0 0 0}$ & $\mathbf{- 1 . 3 0 0}$ & $\mathbf{0 . 3 0 0}$ & -
\end{tabular}

${ }^{\mathrm{a}}$ Generic OPLS-AA charges as implemented in Gromacs ${ }^{47}$

A comparison of the selected charges for the two systems $\left(\mathrm{OH}_{2}\right.$ or $\mathrm{OH}^{-}$forms of the binding site) points out very important differences in charge distribution, especially for the histidine residues and for the hydrogen atoms belonging to the zinc-bound water. The charge difference for the zinc atom is important ( $\sim 0.3)$, but most of the supplementary charge arising from the zinc-bound water deprotonation seems to be redistributed over the whole binding site.

\section{Bonding parameters}

The standard OPLS-AA bonding parameters implemented in Gromacs $\underline{47}$ were used in this work, except for those involving the zinc ion and the zinc-bound water, which were not available. In this latter case, the values for bonds, angles and dihedrals were extracted from the neutron structure $\underline{48}\left(\mathrm{OH}_{2}\right.$ form $)$ or from quantum chemistry calculations $\left(\mathrm{OH}^{-}\right.$form). The other parameters were adapted from those previously published by Maupin et al., ${ }^{28}$ with the exception of the angle N-Zn-O for which the force constant was too weak to keep the binding site's geometry stable (data not shown). We used then a $\sim 5$-fold stronger force constant for this angle (see the Supplementary Data file) which led to stable simulations, as shown below. Free rotation was allowed for dihedral angles involving Zn (X-Zn-N-X and X-Zn-O-X).

\section{Molecular dynamics}

Molecular dynamics simulations in explicit solvent were performed in order to evaluate the validity of the OPLS-AA force field parameters generated in this study. Two simulations, of $10 \mathrm{~ns}$ each, were carried out 
using the neutron structure of carbonic anhydrase II (PDB code $3 \mathrm{KKX})^{4 \underline{48}}$ with both $\mathrm{OH}_{2}$ and $\mathrm{OH}^{-}$forms of the binding site.

The structure proved to be stable for the simulation time, with RMSD values of 1.5-1.9 $\AA$ for the whole protein and 0.25-0.35 $\AA$ for the binding site, which includes the three histidine residues (His94, His96 and His119), the zinc ion and the zinc-bound water. The distances between the zinc ion and its immediate neighbors are also very stable, with values of $1.80 \AA$ for the $\mathrm{Zn}-\mathrm{O}$ bond in the $\mathrm{OH}^{-}$form and $2.30 \AA$ in the $\mathrm{OH}_{2}$ form. The $\mathrm{Zn}-\mathrm{N}$ bonds have a mean value of $2.05 \AA$ in both forms. The angles $\mathrm{N}-\mathrm{Zn}-\mathrm{O}$ are also stable using the new force constant, the angle average and angle distribution showing equilibrium values of $\sim 117^{\circ}$ and $\sim 113^{\circ}$ for the $\mathrm{OH}_{2}$ and $\mathrm{OH}^{-}$forms of the binding site, respectively. All these plots can be found in the Supplementary Data file.

\section{Conclusions}

In this work, the carbonic anhydrase binding site parameterization was performed using quantum chemistry calculations and these parameters were subsequently validated using molecular dynamics simulations. Important differences in terms of atomic partial charges were obtained for the $\mathrm{OH}_{2}$ and $\mathrm{OH}^{-}$forms of the binding site, showing that the supplementary charge induced by the zinc-bound water deprotonation has a significant influence on residues from the entire binding site. The force field parameters and topologies generated in this work will be useful for future molecular dynamics studies of carbonic anhydrase using the OPLS-AA force field.

\section{Materials and methods}

\section{Charge calculation}

The geometry of each system was optimized in gas-phase using the Gaussian 09 package ${ }^{50}$ using the Hartree-Fock method, $\underline{51}$ the Becke's three-parameter hybrid exchange functional (B3LYP) $2 \frac{53}{53}$ or the Møller-Plesset perturbation method (MP2), $\underline{54}$ with either the $6-31 \mathrm{G}(\mathrm{d})$ or $6-311++\mathrm{G}(2 \mathrm{~d}, \mathrm{p})$ basis sets. CHelpG charges were calculated at the same level, then a two-stage RESP fitting was carried out using using AmberTools. $\underline{55}$ This methodology has been previously used for heterocycles parameterization in the 
OPLS-AA force field $\underline{56}, \underline{57}$ and found to be the most appropriate for the OPLS-AA parameterization of the SAMPL3 dataset. $\underline{45}$

\section{Molecular dynamics}

Molecular dynamics simulations were performed using GROMACS version 4.5.4 $\underline{47}$ with the OPLS-AA $\underline{41}, \underline{42}$ force field. The system was constructed by positioning the protein in a cubic periodic box of TIP4P waters, with a minimum distance of $1.0 \mathrm{~nm}$ on each side. The simulation box, obtained after hydration and neutralization with $\mathrm{Na}^{+}$and $\mathrm{Cl}^{-}$ions to physiological ionic strength $(150 \mathrm{mM})$, contained about 62,000 atoms (protein, water and ions). The system was energy-minimized until convergence using a steepest descents algorithm to remove close contacts of water molecules with the solute. Molecular dynamics simulation with position restraints on the solute atoms was then performed for 200 ps to relax the water molecules around the solute, followed by the production run of $10 \mathrm{~ns}$. During the position restraints and production runs, the Berendsen method $\frac{58}{5}$ was used for pressure and temperature coupling. Electrostatics were calculated with the particle mesh Ewald method. $\underline{59}, \underline{60}$ The P-LINCS algorithm $\underline{61}$ was used to constrain bond lengths, and a time step of $2 \mathrm{fs}$ was used throughout. All simulations were performed using constant temperature, pressure, and number of particles (NPT) and periodic boundary conditions. The cut-off distance for Lennard-Jones interactions and electrostatic interactions were both set at $1.0 \mathrm{~nm}$.

OPLS-AA force field topologies for the binding site residues were generated with an in-house developed script, using the charges presented in Tables 1 and 2 and the parameters described in the Supplementary Data file.

\section{Miscellaneous}

Structure images were rendered using Chimera. $\frac{62}{}$ Molecular dynamics analysis plots were generated with XmGrace.$\underline{63}$

All calculations were performed using the high-performance computing (HPC) facilities at the Institut de Chimie des Substances Naturelles, Gif sur Yvette, France.

\section{Acknowledgments}


Our laboratory is a member of the Laboratory of Excellence LERMIT supported by a grant from ANR (ANR-10-LABX-33).

\section{Supplementary Material}

Supplementary data are available online, containing i) a detailed analysis of the molecular dynamics simulations and ii) the OPLS-AA force field parameters in the appropriate format for use with the Gromacs software.

\section{References and notes}

1. Mincione, F.; Scozzafava, A.; Supuran, C. T. Curr. Pharm. Des. 2008, 14, 649.

2. Gugleta, K. Curr. Med. Res. Opin. 2010, 26, 1255.

3. Pastorekova, S.; Zatovicova, M.; Pastorek, J. Curr. Pharm. Des. 2008, 14, 685.

4. Thiry, A.; Supuran, C. T.; Masereel, B.; Dogne, J. M. J. Med. Chem. 2008, 51, 3051.

5. Winum, J. Y.; Scozzafava, A.; Montero, J. L.; Supuran, C. T. Anticancer Agents Med. Chem. 2009, 9, 693.

6. Guler, O. O.; De Simone, G.; Supuran, C. T. Curr. Med. Chem. 2010, 17, 1516.

7. Poulsen, S. A. Expert Opin. Ther. Pat. 2010, 20, 795.

8. De Simone, G.; Di Fiore, A.; Supuran, C. T. Curr. Pharm. Des. 2008, 14, 655.

9. Supuran, C. T.; Di Fiore, A.; De Simone, G. Expert Opin. Emerg. Drugs 2008, 13, 383.

10. Thiry, A.; Dogne, J. M.; Supuran, C. T.; Masereel, B. Curr. Pharm. Des. 2008, 14, 661.

11. Temperini, C.; Scozzafava, A.; Supuran, C. T. Curr. Pharm. Des. 2008, 14, 708.

12. Supuran, C. T. Curr. Pharm. Des. 2008, 14, 603.

13. Supuran, C. T. Nat. Rev. Drug Discov. 2008, 7, 168.

14. Supuran, C. T. Bioorg. Med. Chem. Lett. 2010, 20, 3467.

15. Gilmour, K. M. Comp. Biochem. Physiol. A Mol. Integr. Physiol. 2010, 157, 193.

16. Supuran, C. T. Future Med. Chem. 2011, 3, 1165.

17. Åqvist, J.; Warshel, A. J. Mol. Biol. 1992, 224, 7. 
18. Housaindokht, M. R.; Bozorgmehr, M. R.; Bahrololoom, M. J. Theor. Biol. 2008, 254, 294.

19. Bozorgmehr, M. R.; Morsali, A.; Beyramabadi, S. A. Int. J. Phys. Sci. 2012, 7.

20. Stote, R. H.; Karplus, M. Proteins 1995, 23, 12.

21. Lu, D.; Voth, G. A. Proteins 1998, 33, 119.

22. Roy, A.; Taraphder, S. J. Phys. Chem. B 2009, 113, 12555.

23. Zhang, J.-L.; Zheng, Q.-C.; Zhang, H.-X. Comput. Biol. Chem. 2011, 35, 50.

24. Schmid, M.; Nogueira, E. S.; Monnard, F. W.; Ward, T. R.; Meuwly, M. Chem. Sci. 2012.

25. Ohta, S.; Alam, M. T.; Arakawa, H.; Ikai, A. Biophys. J. 2004, 87, 4007.

26. Vitale, R. M.; Pedone, C.; Amodeo, P.; Antel, J.; Wurl, M.; Scozzafava, A.; Supuran, C. T.; Simone, G. D. Bioorg. Med. Chem. 2007, 15, 4152.

27. Fisher, S. Z.; Maupin, C. M.; Budayova-Spano, M.; Govindasamy, L.; Tu, C.; Agbandje-McKenna, M.; Silverman, D. N.; Voth, G. A.; McKenna, R. Biochemistry 2007, 46, 2930.

28. Maupin, C. M.; Voth, G. A. Biochemistry 2007, 46, 2938.

29. Maupin, C. M.; Saunders, M. G.; Thorpe, I. F.; McKenna, R.; Silverman, D. N.; Voth, G. A. J. Am. Chem. Soc. 2008, 130, 11399.

30. Král, V.; Mader, P.; Collard, R.; Fábry, M.; Hořejší, M.; Řezáčová, P.; Kožíšek, M.; Závada, J.; Sedláček, J.; Rulíšek, L.; Brynda, J. Proteins 2008, 71, 1275.

31. Maupin, C. M.; McKenna, R.; Silverman, D. N.; Voth, G. A. J. Am. Chem. Soc. 2009, 131, 7598.

32. Maupin, C. M.; Voth, G. A. Biochim. Biophys. Acta 2010, 1804, 332.

33. Alterio, V.; Vitale, R. M.; Monti, S. M.; Pedone, C.; Scozzafava, A.; Cecchi, A.; De Simone, G.; Supuran, C. T. J. Am. Chem. Soc. 2006, 128, 8329.

34. D'Ambrosio, K.; Vitale, R.-M.; Dogné, J.-M.; Masereel, B.; Innocenti, A.; Scozzafava, A.; De Simone, G.; Supuran, C. T. J. Med. Chem. 2008, 51, 3230.

35. Vitale, R. M.; Alterio, V.; Innocenti, A.; Winum, J.-Y.; Monti, S. M.; De Simone, G.; Supuran, C. T. J. Med. Chem. 2009, 52, 5990.

36. Peters, M. B.; Yang, Y.; Wang, B.; Füsti-Molnár, L.; Weaver, M. N.; Merz Jr, K. M. J. Chem. Theory Comput. 2010, 6, 2935. 
37. Loferer, M. J.; Tautermann, C. S.; Loeffler, H. H.; Liedl, K. R. J. Am. Chem. Soc. 2003, 125, 8921.

38. Braun-Sand, S.; Strajbl, M.; Warshel, A. Biophys. J. 2004, 87, 2221.

39. Riccardi, D.; Yang, S.; Cui, Q. Biochim. Biophys. Acta 2010, 1804, 342.

40. Banci, L. Curr. Opin. Chem. Biol. 2003, 7, 143.

41. Jorgensen, W. L.; Maxwell, D. S.; Tirado-Rives, J. J. Am. Chem. Soc. 1996, 118, 11225.

42. Kaminski, G. A.; Friesner, R. A.; Tirado-Rives, J.; Jorgensen, W. L. J. Phys. Chem. B 2001, 105, 6474.

43. Shirts, M. R.; Pitera, J. W.; Swope, W. C.; Pande, V. S. J. Chem. Phys. 2003, 119, 5740.

44. Shivakumar, D.; Williams, J.; Wu, Y.; Damm, W.; Shelley, J.; Sherman, W. J. Chem. Theory Comput. 2010, 6, 1509.

45. Beckstein, O.; Iorga, B. I. J Comput Aided Mol Des 2012, 26, 635.

46. Jorgensen, W. L.; Schyman, P. J. Chem. Theory Comput. 2012, in press (DOI: 10.1021/ct300180w).

47. Hess, B.; Kutzner, C.; van der Spoel, D.; Lindahl, E. J. Chem. Theory Comput. 2008, 4, 435.

48. Fisher, S. Z.; Kovalevsky, A. Y.; Domsic, J. F.; Mustyakimov, M.; McKenna, R.; Silverman, D. N.; Langan, P. A. Biochemistry 2010, 49, 415.

49. Frison, G.; Ohanessian, G. Phys. Chem. Chem. Phys. 2009, 11, 374.

50. Frisch, M. J.; Trucks, G. W.; Schlegel, H. B.; Scuseria, G. E.; Robb, M. A.; Cheeseman, J. R.; Scalmani, G.; Barone, V.; Mennucci, B.; Petersson, G. A.; Nakatsuji, H.; Caricato, M.; Li, X.; Hratchian, H. P.; Izmaylov, A. F.; Bloino, J.; Zheng, G.; Sonnenberg, J. L.; Hada, M.; Ehara, M.; Toyota, K.; Fukuda, R.; Hasegawa, J.; Ishida, M.; Nakajima, T.; Honda, Y.; Kitao, O.; Nakai, H.; Vreven, T.; Montgomery Jr., J. A.; Peralta, J. E.; Ogliaro, F.; Bearpark, M.; Heyd, J. J.; Brothers, E.; Kudin, K. N.; Staroverov, V. N.; Kobayashi, R.; Normand, J.; Raghavachari, K.; Rendell, A.; Burant, J. C.; Iyengar, S. S.; Tomasi, J.; Cossi, M.; Rega, N.; Millam, N. J.; Klene, M.; Knox, J. E.; Cross, J. B.; Bakken, V.; Adamo, C.; Jaramillo, J.; Gomperts, R.; Stratmann, R. E.; Yazyev, O.; Austin, A. J.; Cammi, R.; Pomelli, C.; Ochterski, J. W.; Martin, R. L.; Morokuma, K.; Zakrzewski, V. G.; Voth, G. A.; Salvador, P.; Dannenberg, J. J.; Dapprich, S.; Daniels, A. D.; Farkas, Ö.; Foresman, J. B.; 
Ortiz, J. V.; Cioslowski, J.; Fox, D. J. Gaussian 09, Revision A.2, Gaussian Inc., Wallingford CT, USA (http://www.gaussian.com).

51. Slater, J. C. Phys. Rev. 1951, 81, 385.

52. Lee, C.; Yang, W.; Parr, R. G. Phys. Rev. B 1988, 37, 785.

53. Becke, A. D. J. Chem. Phys. 1993, 98, 5648.

54. Møller, C.; Plesset, M. S. Phys. Rev. 1934, 46, 618.

55. Iorga, B.; Eymery, F.; Savignac, P. Tetrahedron Lett 1998, 39, 4477.

56. Jorgensen, W. L.; McDonald, N. A. J. Mol. Struct. THEOCHEM 1998, 424, 145.

57. McDonald, N. A.; Jorgensen, W. L. J. Phys. Chem. B 1998, 102, 8049.

58. Berendsen, H. J. C.; Postma, J. P. M.; van Gunsteren, W. F.; DiNola, A.; Haak, J. R. J. Chem. Phys. 1984, $81,3684$.

59. Darden, T.; York, D.; Pedersen, L. G. J. Chem. Phys. 1993, 98, 10089.

60. Essmann, U.; Perera, L.; Berkowitz, M.; Darden, T.; Lee, H.; Pedersen, L. J. Chem. Phys. 1995, 103, 8577.

61. Hess, B. J. Chem. Theory Comput. 2007, 4, 116.

62. Pettersen, E. F.; Goddard, T. D.; Huang, C. C.; Couch, G. S.; Greenblatt, D. M.; Meng, E. C.; Ferrin, T. E. J. Comput. Chem. 2004, 25, 1605.

63. Scozzafava, A.; Iorga, B.; Supuran, C. T. J. Enz. Inhib. 2000, 15, 139. 


\title{
Supporting information \\ Carbonic anhydrase binding site parameterization in OPLS-AA force field
}

\author{
Guillaume Bernadat, ${ }^{a}$ Claudiu T. Supuran ${ }^{\mathrm{b}}$ and Bogdan I. Iorga ${ }^{\mathrm{a},{ }^{*}}$ \\ a Institut de Chimie des Substances Naturelles, CNRS UPR 2301, Labex LERMIT, Centre de Recherche de Gif, \\ 1 Avenue de la Terrasse, 91198 Gif-sur-Yvette, France \\ ${ }^{\mathrm{b}}$ Dipartimento di Chimica, Laboratorio di Chimica Bioinorganica, Università degli Studi di Firenze, Rm 188, Via \\ della Lastruccia 3, Polo Scientifico, I-50019 Sesto Fiorentino (Firenze), Italy
}

Validation of carbonic anhydrase binding site parameterization in OPLS-AA force field, using molecular dynamics, for both $\mathrm{OH}^{-}$and $\mathrm{OH}_{2}$ forms

Plots of:

- root mean square distance (RMSD) for protein and binding site

- distance between $\mathrm{Zn}$ and its coordinating atoms

- angle average and distribution for OW-Zn-N(HIS)
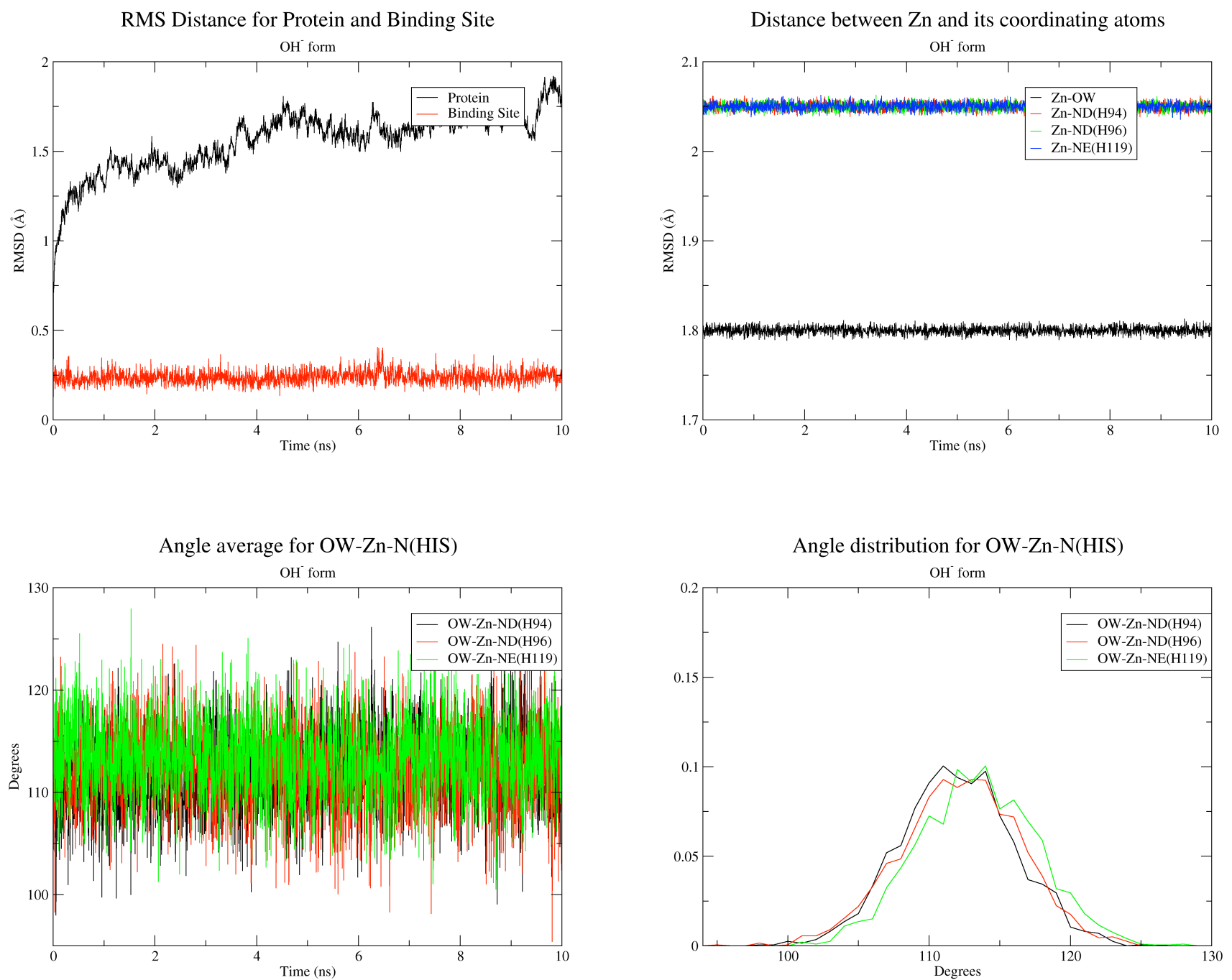
RMS Distance for Protein and Binding Site $\mathrm{OH}_{2}$ form

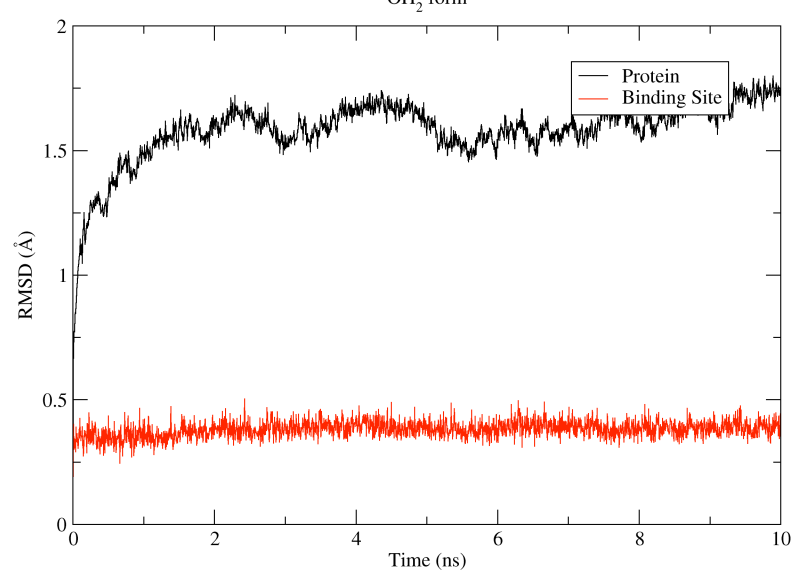

Angle average for OW-Zn-N(HIS) $\mathrm{OH}_{2}$ form

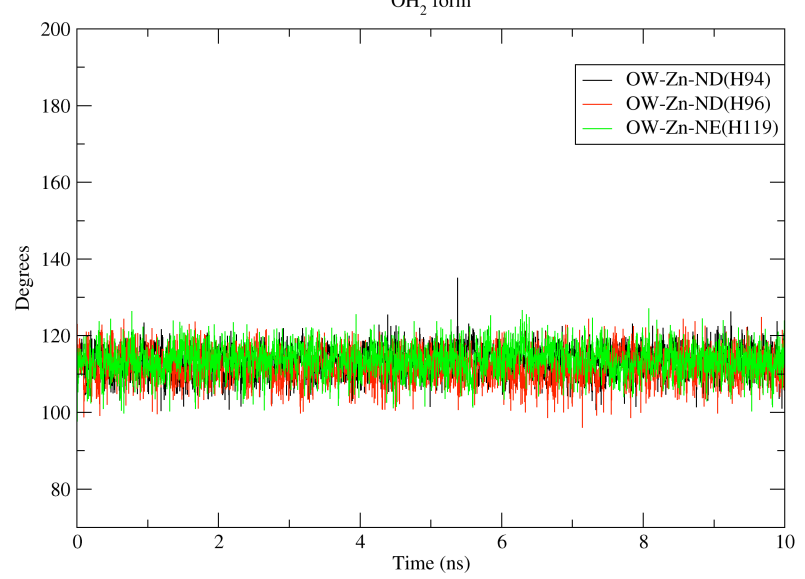

Distance between $\mathrm{Zn}$ and its coordinating atoms $\mathrm{OH}_{2}$ form

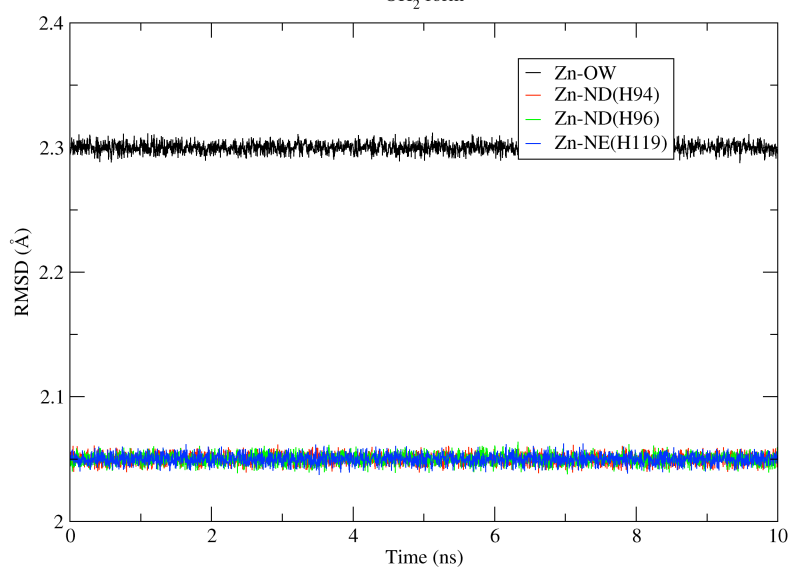

Angle distribution for OW-Zn-N(HIS)

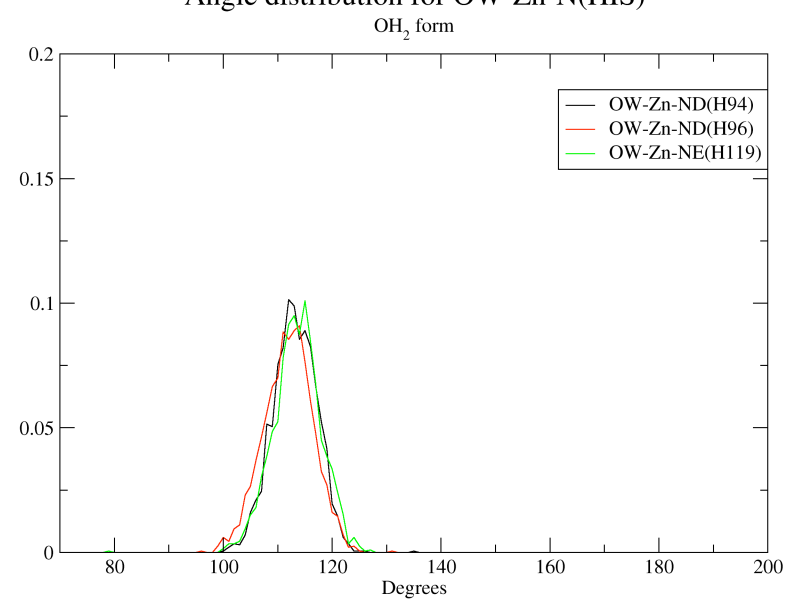


Modifications required for the PDB input files and for OPLS-AA files as implemented in Gromacs 4.5.4

\section{PDB input files}

Residues corresponding to HIS94, HIS96 and HIS119 should be renamed as following (example for the $3 \mathrm{KKX}$ structure). The zinc atom and the zinc-bound water should belong to the HIS119 residue.

\section{- $\mathrm{OH}^{-}$form}

\begin{tabular}{|c|c|c|c|c|c|}
\hline АТОМ & 733 & $\mathrm{~N}$ & $\mathrm{H} 2 \mathrm{D}$ & A & 9 \\
\hline АTOM & 734 & CA & $\mathrm{H} 2 \mathrm{D}$ & A & \\
\hline ATOM & 735 & C & $\mathrm{H} 2 \mathrm{D}$ & A & \\
\hline TOM & 736 & 0 & $\mathrm{H} 2 \mathrm{D}$ & A & \\
\hline TOM & 737 & $\mathrm{CB}$ & $\mathrm{H} 2 \mathrm{D}$ & A & \\
\hline TOM & 738 & CG & $\mathrm{H} 2 \mathrm{D}$ & A & \\
\hline ATOM & 739 & ND1 & $\mathrm{H} 2 \mathrm{D}$ & A & \\
\hline TOM & 740 & CD2 & $\mathrm{H} 2 \mathrm{D}$ & A & \\
\hline TOM & 741 & $\mathrm{CE} 1$ & $\mathrm{H} 2 \mathrm{D}$ & A & \\
\hline TOM & 742 & $\mathrm{NE} 2$ & $\mathrm{H} 2 \mathrm{D}$ & A & \\
\hline \\
\hline ГOM & 754 & $\mathrm{~N}$ & $\mathrm{H} 2 \mathrm{D}$ & A & \\
\hline TOM & 755 & $\mathrm{CA}$ & $\mathrm{H} 2 \mathrm{D}$ & A & \\
\hline TOM & 756 & $C$ & $\mathrm{H} 2 \mathrm{D}$ & A & \\
\hline TOM & 757 & 0 & $\mathrm{H} 2 \mathrm{D}$ & A & \\
\hline TOM & 758 & CB & $\mathrm{H} 2 \mathrm{D}$ & A & \\
\hline TOM & 759 & CG & $\mathrm{H} 2 \mathrm{D}$ & $\mathrm{A}$ & \\
\hline TOM & 760 & ND1 & $\mathrm{H} 2 \mathrm{D}$ & A & \\
\hline TOM & 761 & CD2 & $\mathrm{H} 2 \mathrm{D}$ & A & \\
\hline АTOM & 762 & $\mathrm{CE} 1$ & $\mathrm{H} 2 \mathrm{D}$ & A & \\
\hline ATOM & 763 & NE2 & $\mathrm{H} 2 \mathrm{D}$ & $A$ & \\
\hline \multicolumn{6}{|l|}{... } \\
\hline OM & 934 & $\mathrm{~N}$ & $\mathrm{H} 2 \mathrm{E}$ & A & \\
\hline $\mathrm{OM}$ & 935 & $\mathrm{CA}$ & $\mathrm{H} 2 \mathrm{E}$ & A & \\
\hline TOM & 936 & $C$ & $\mathrm{H} 2 \mathrm{E}$ & $\mathrm{A}$ & 1. \\
\hline TOM & 937 & 0 & $\mathrm{H} 2 \mathrm{E}$ & $\mathrm{A}$ & 11 \\
\hline ATOM & 938 & $\mathrm{CB}$ & $\mathrm{H} 2 \mathrm{E}$ & $\mathrm{A}$ & 1. \\
\hline АTOM & 939 & CG & $\mathrm{H} 2 \mathrm{E}$ & A & 11 \\
\hline ATOM & 940 & ND1 & $\mathrm{H} 2 \mathrm{E}$ & A & 11 \\
\hline АTOM & 941 & CD2 & $\mathrm{H} 2 \mathrm{E}$ & $\mathrm{A}$ & 11 \\
\hline ATOM & 942 & $\mathrm{CE} 1$ & $\mathrm{H} 2 \mathrm{E}$ & A & \\
\hline АTOM & 943 & $\mathrm{NE} 2$ & $\mathrm{H} 2 \mathrm{E}$ & A & \\
\hline TOM & 2060 & $\mathrm{ZN}$ & $\mathrm{H} 2 \mathrm{E}$ & A & \\
\hline АTOM & 2061 & OW & $\mathrm{H} 2 \mathrm{E}$ & A & \\
\hline
\end{tabular}

- $\mathrm{OH}_{2}$ form

$\begin{array}{llllll}\text { ATOM } & 733 & \text { N } & \text { H1D A } & 94 \\ \text { ATOM } & 734 & \text { CA } & \text { H1D A } & 94 \\ \text { ATOM } & 735 & \text { C } & \text { H1D A } & 94 \\ \text { ATOM } & 736 & \text { O } & \text { H1D A } & 94 \\ \text { ATOM } & 737 & \text { CB } & \text { H1D A } & 94 \\ \text { ATOM } & 738 & \text { CG } & \text { H1D A } & 94 \\ \text { ATOM } & 739 & \text { ND1 } & \text { H1D A } & 94 \\ \text { ATOM } & 740 & \text { CD2 } & \text { H1D A } & 94 \\ \text { ATOM } & 741 & \text { CE1 } & \text { H1D A } & 94 \\ \text { ATOM } & 742 & \text { NE2 } & \text { H1D A } & 94 \\ \ldots & & & & & \\ \text { ATOM } & 754 & \text { N } & \text { H1D A } & 96 \\ \text { ATOM } & 755 & \text { CA } & \text { H1D A } & 96 \\ \text { ATOM } & 756 & \text { C } & \text { H1D A } & 96 \\ \text { ATOM } & 757 & \text { O } & \text { H1D A } & 96\end{array}$

\begin{tabular}{|c|c|c|c|c|}
\hline 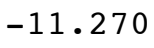 & 0.912 & 0.982 & 00 & \\
\hline-10 & -1.868 & 10.387 & 00 & \\
\hline 0. & 3.168 & 1.181 & & 1 \\
\hline 11. & & 2.237 & & \\
\hline & -1. & 0.333 & & \\
\hline-8 & -1.070 & 1.697 & 00 & \\
\hline & 0 . & 01 & & \\
\hline & -1 . & 598 & & \\
\hline-7 & 0 . & 24 & & \\
\hline-7 . & 1. & 3.705 & .00 & \\
\hline-8 & -6 . & 9 & & \\
\hline-6 . & -7 . & 6 & & \\
\hline-7.334 & -9.133 & 12.494 & 00 & \\
\hline-8 & -9 & 12 . & 00 & \\
\hline-6 & -7 . & 14 . & 00 & \\
\hline-6 & -6.01 & 14.337 & .00 & \\
\hline-4 & -5 & 14 . & 00 & \\
\hline-6 . & -5 . & 14. & 0 & \\
\hline-4 & -4 & 67 & 00 & \\
\hline-6 & 2 & 11 & & \\
\hline 11 . & -3 & 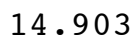 & & \\
\hline 11. & -1 & 4 & 0 & \\
\hline-12 . & -0 . & 14.964 & 1.00 & \\
\hline-12 . & -0 & 13.831 & 00 & \\
\hline 10 . & -1 & 15. & 1 . & \\
\hline-9. & -2 . & 16 . & 1.00 & \\
\hline-8 . & -2 . & 16.674 & 1.00 & \\
\hline 10 & .36 & 17.544 & 0 & \\
\hline-7 & -3. & 17 . & & \\
\hline-9 & -4 & 18.131 & 1.00 & \\
\hline & & & & \\
\hline & .838 & 16.084 & 1.00 & \\
\hline
\end{tabular}

N
C
C
O
C
C
N
C
C
N

N
C
C
O
C
C
N
C
C
N

N
C
C
O
C
C
N
C
C
N
O

$\begin{array}{rrrrr}-11.270 & -0.912 & 10.982 & 1.00 & 13.80 \\ -10.338 & -1.868 & 10.387 & 1.00 & 14.21 \\ -10.428 & -3.168 & 11.181 & 1.00 & 14.70 \\ -11.030 & -3.183 & 12.237 & 1.00 & 14.38 \\ -8.880 & -1.336 & 10.333 & 1.00 & 14.21 \\ -8.350 & -1.070 & 11.697 & 1.00 & 13.64 \\ -8.429 & 0.175 & 12.301 & 1.00 & 15.01 \\ -7.757 & -1.906 & 12.598 & 1.00 & 13.69 \\ -7.892 & 0.088 & 13.524 & 1.00 & 14.16 \\ -7.483 & -1.169 & 13.705 & 1.00 & 12.81 \\ -8.103 & -6.883 & 12.469 & 1.00 & 13.66 \\ -6.895 & -7.669 & 12.656 & 1.00 & 14.25 \\ -7.334 & -9.133 & 12.494 & 1.00 & 14.61 \\ -8.426 & -9.505 & 12.965 & 1.00 & 15.41\end{array}$

N
C
O
C
C
N
C
C
N
N
C
C
O 


\begin{tabular}{|c|c|c|c|c|c|c|c|c|c|c|c|}
\hline АTOM & 758 & $\mathrm{CB}$ & $\mathrm{H} 1 \mathrm{D}$ & A & 96 & -6.290 & -7.457 & 14.042 & 1.00 & 14.92 & $\mathrm{C}$ \\
\hline АTOM & 759 & CG & $\mathrm{H} 1 \mathrm{D}$ & A & 96 & -6.025 & -6.011 & 14.337 & 1.00 & 13.72 & C \\
\hline ATOM & 760 & ND1 & H1D & A & 96 & -4.794 & -5.461 & 14.134 & 1.00 & 15.69 & $\mathrm{~N}$ \\
\hline АTOM & 761 & CD2 & $\mathrm{H} 1 \mathrm{D}$ & A & 96 & -6.871 & -5.021 & 14.766 & 1.00 & 15.31 & $\mathrm{C}$ \\
\hline АTOM & 762 & $\mathrm{CE} 1$ & $\mathrm{H} 1 \mathrm{D}$ & $\mathrm{A}$ & 96 & -4.879 & -4.148 & 14.467 & 1.00 & 12.87 & C \\
\hline АTOM & 763 & $\mathrm{NE} 2$ & $\mathrm{H} 1 \mathrm{D}$ & A & 96 & -6.117 & -3.878 & 14.841 & 1.00 & 14.53 & T \\
\hline$\ldots$ & & & & & & & & & & & \\
\hline ATOM & 934 & $\mathrm{~N}$ & $\mathrm{H} 1 \mathrm{E}$ & A & 119 & -11.996 & -3.099 & 14.903 & 1.00 & 13.18 & $\mathrm{~N}$ \\
\hline ATOM & 935 & $\mathrm{CA}$ & $\mathrm{H} 1 \mathrm{E}$ & A & 119 & -11.779 & -1.864 & 15.644 & 1.00 & 12.59 & $\mathrm{C}$ \\
\hline ATOM & 936 & $\mathrm{C}$ & $\mathrm{H} 1 \mathrm{E}$ & A & 119 & -12.488 & -0.684 & 14.964 & 1.00 & 13.77 & C \\
\hline ATOM & 937 & 0 & $\mathrm{H} 1 \mathrm{E}$ & A & 119 & -12.120 & -0.370 & 13.831 & 1.00 & 14.33 & 0 \\
\hline ATOM & 938 & $\mathrm{CB}$ & $\mathrm{H} 1 \mathrm{E}$ & A & 119 & -10.263 & -1.553 & 15.732 & 1.00 & 13.09 & 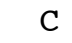 \\
\hline АTOM & 939 & CG & $\mathrm{H} 1 \mathrm{E}$ & A & 119 & -9.561 & -2.520 & 16.621 & 1.00 & 13.90 & $\mathrm{C}$ \\
\hline ATOM & 940 & ND1 & $\mathrm{H} 1 \mathrm{E}$ & A & 119 & -8.209 & -2.718 & 16.674 & 1.00 & 15.24 & N \\
\hline ATOM & 941 & CD2 & $\mathrm{H} 1 \mathrm{E}$ & A & 119 & -10.105 & -3.367 & 17.544 & 1.00 & 13.82 & $\mathrm{C}$ \\
\hline ATOM & 942 & $\mathrm{CE} 1$ & $\mathrm{H} 1 \mathrm{E}$ & A & 119 & -7.901 & -3.630 & 17.567 & 1.00 & 14.62 & $\mathrm{C}$ \\
\hline АTOM & 943 & $\mathrm{NE} 2$ & $\mathrm{H} 1 \mathrm{E}$ & A & 119 & -9.042 & -4.049 & 18.131 & 1.00 & 14.93 & 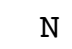 \\
\hline ATOM & 2060 & $\mathrm{ZN}$ & $\mathrm{H} 1 \mathrm{E}$ & A & 119 & -6.735 & -2.066 & 15.380 & 1.00 & 14.83 & \\
\hline АTOM & 2061 & OW & $\mathrm{H} 1 \mathrm{E}$ & $\mathrm{A}$ & 119 & -5.366 & -0.838 & 16.084 & 1.00 & 17.01 & 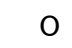 \\
\hline
\end{tabular}

\section{OPLS-AA Gromacs files}

The following lines should be added to the files mentioned below, in the corresponding sections.

\section{- aminoacids.rtp}

[ H1D ] ; HISD bound to $\mathrm{Zn}$ for $\mathrm{CA}$ (OH2 form) [ atoms ]

$\begin{array}{rlrl}\text { N } & \text { opls_238 } & -0.500 & 1 \\ \text { H } & \text { opls_241 } & 0.300 & 1 \\ \text { CA } & \text { opls_224B } & 0.140 & 1 \\ \text { HA } & \text { opls_140 } & 0.060 & 1 \\ \text { CB } & \text { opls_505 } & -0.038 & 2 \\ \text { HB1 } & \text { opls_140 } & 0.099 & 2 \\ \text { HB2 } & \text { opls_140 } & 0.099 & 2 \\ \text { CG } & \text { opls_508 } & 0.228 & 3 \\ \text { ND1 } & \text { opls_503 } & -0.332 & 4 \\ \text { HD1 } & \text { opls_504 } & 0.384 & 4 \\ \text { CD2 } & \text { opls_507 } & -0.311 & 5 \\ \text { HD2 } & \text { opls_146 } & 0.197 & 5 \\ \text { CE1 } & \text { opls_506 } & 0.110 & 6 \\ \text { HE1 } & \text { opls_146 } & 0.140 & 6 \\ \text { NE2 } & \text { opls_511 } & -0.123 & 7 \\ \text { C } & \text { opls_235 } & 0.500 & 8 \\ \text { O } & \text { opls_236 } & -0.500 & 8\end{array}$

[ bonds ]

$\begin{array}{rr}\mathrm{N} & \mathrm{H} \\ \mathrm{N} & \mathrm{CA} \\ \mathrm{CA} & \mathrm{HA} \\ \mathrm{CA} & \mathrm{CB} \\ \mathrm{CA} & \mathrm{C}\end{array}$

$\mathrm{CB} \quad \mathrm{HB} 1$

$\mathrm{CB} \quad \mathrm{HB} 2$

CB $\quad$ CG

CG ND1

CG $\quad$ CD2

ND1 HD1

ND1 CE1

CD2 HD2

CD2 NE2

CE 1 HE 1

CE1 NE2

$\begin{array}{rr}\mathrm{C} & \mathrm{O} \\ -\mathrm{C} & \mathrm{N}\end{array}$




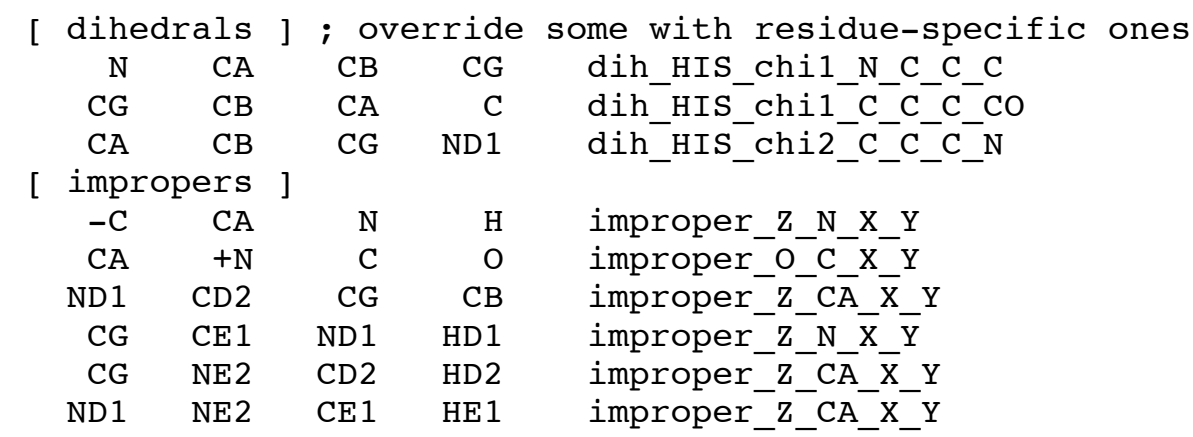

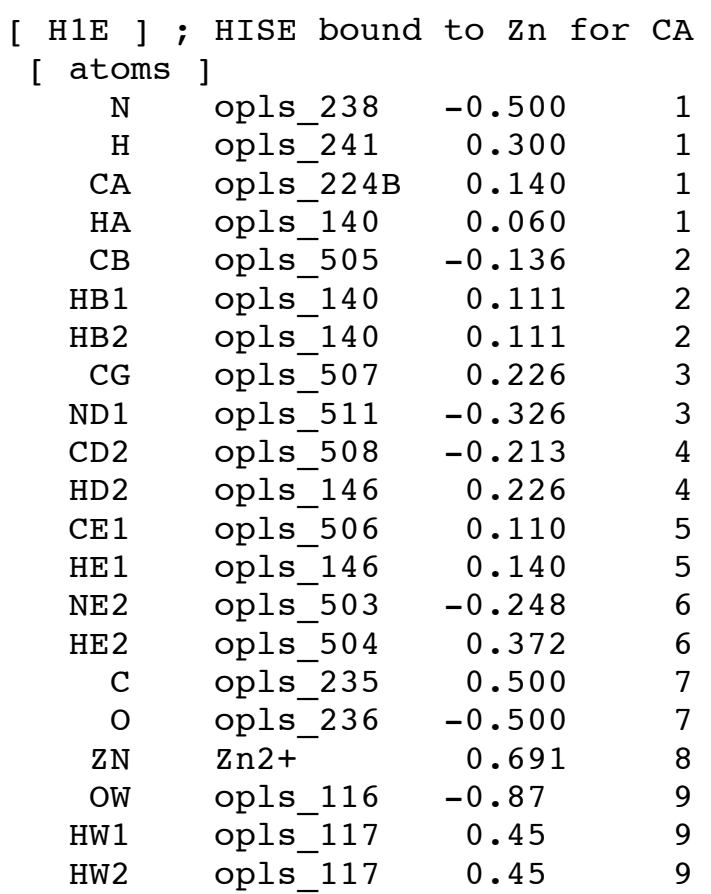

[ bonds ]

$\begin{array}{rr}\mathrm{N} & \mathrm{H} \\ \mathrm{N} & \mathrm{CA} \\ \mathrm{CA} & \mathrm{HA} \\ \mathrm{CA} & \mathrm{CB} \\ \mathrm{CA} & \mathrm{C} \\ \mathrm{CB} & \mathrm{HB} 1 \\ \mathrm{CB} & \mathrm{HB} 2 \\ \mathrm{CB} & \mathrm{CG} \\ \mathrm{CG} & \mathrm{ND} 1 \\ \mathrm{CG} & \mathrm{CD} 2 \\ \mathrm{ND} 1 & \mathrm{CE} 1 \\ \mathrm{CD} 2 & \mathrm{HD} 2 \\ \mathrm{CD} 2 & \mathrm{NE} 2 \\ \mathrm{CE} 1 & \mathrm{HE} 1 \\ \mathrm{CE} 1 & \mathrm{NE} 2 \\ \mathrm{NE} 2 & \mathrm{HE} 2 \\ \mathrm{C} & \mathrm{O} \\ -\mathrm{C} & \mathrm{N} \\ \mathrm{ZN} & \mathrm{ND} 1 \\ \mathrm{OW} & \mathrm{HW} 1 \\ \mathrm{OW} & \mathrm{HW} 2 \\ \mathrm{ZN} & \mathrm{OW}\end{array}$

Biochemistry, 2007, 46, 2938)

[ angles ]

HW OW HW $104.500 \quad 418.500 ; 4.185 * 100$ (adapted from Maupin,

Biochemistry, $2007,46,2938$ )

[ dihedrals ] ; override some with residue-specific ones
$\mathrm{N}$
$\mathrm{CA}$
CB $\quad$ CG
dih_HIS_chi1_N_C_C_C 


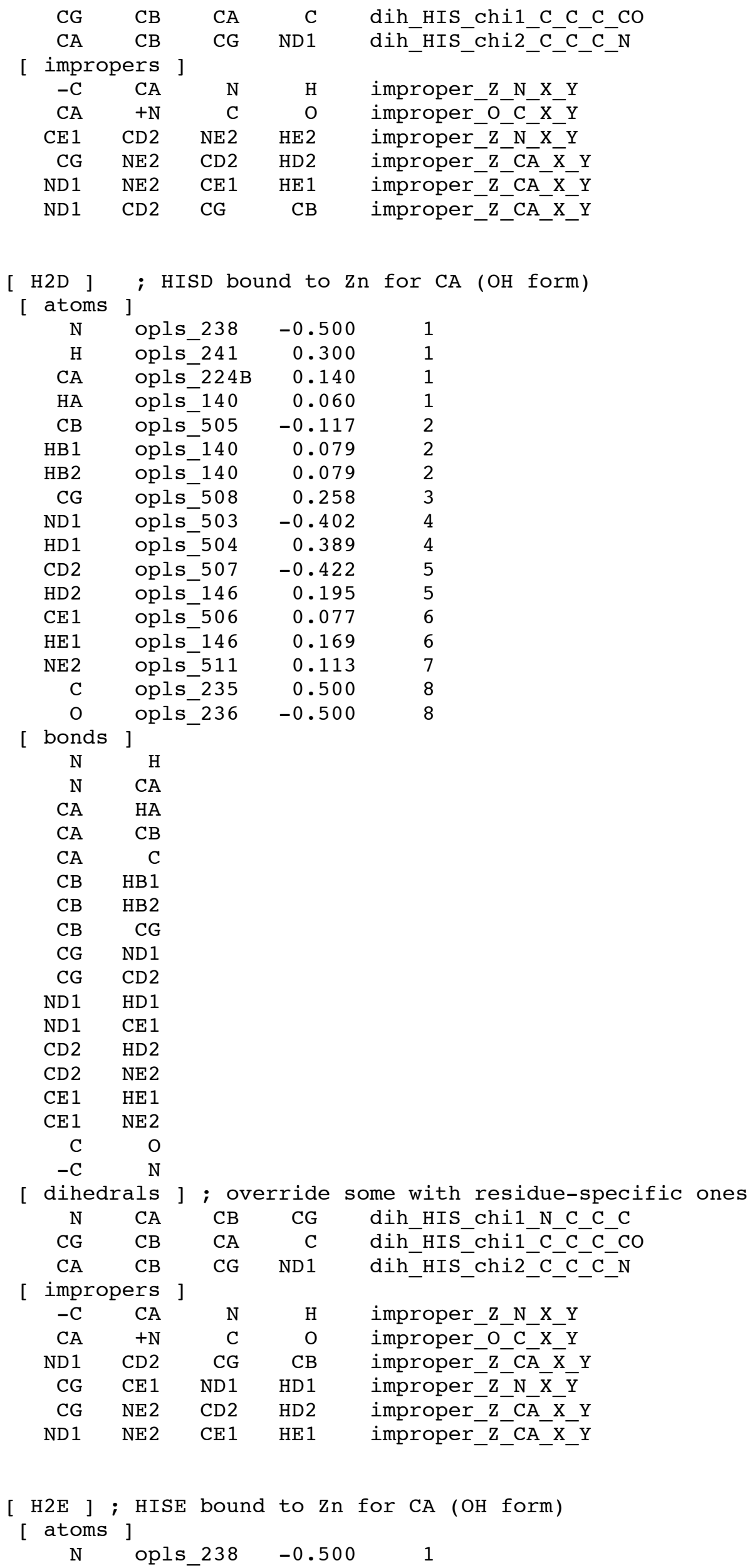




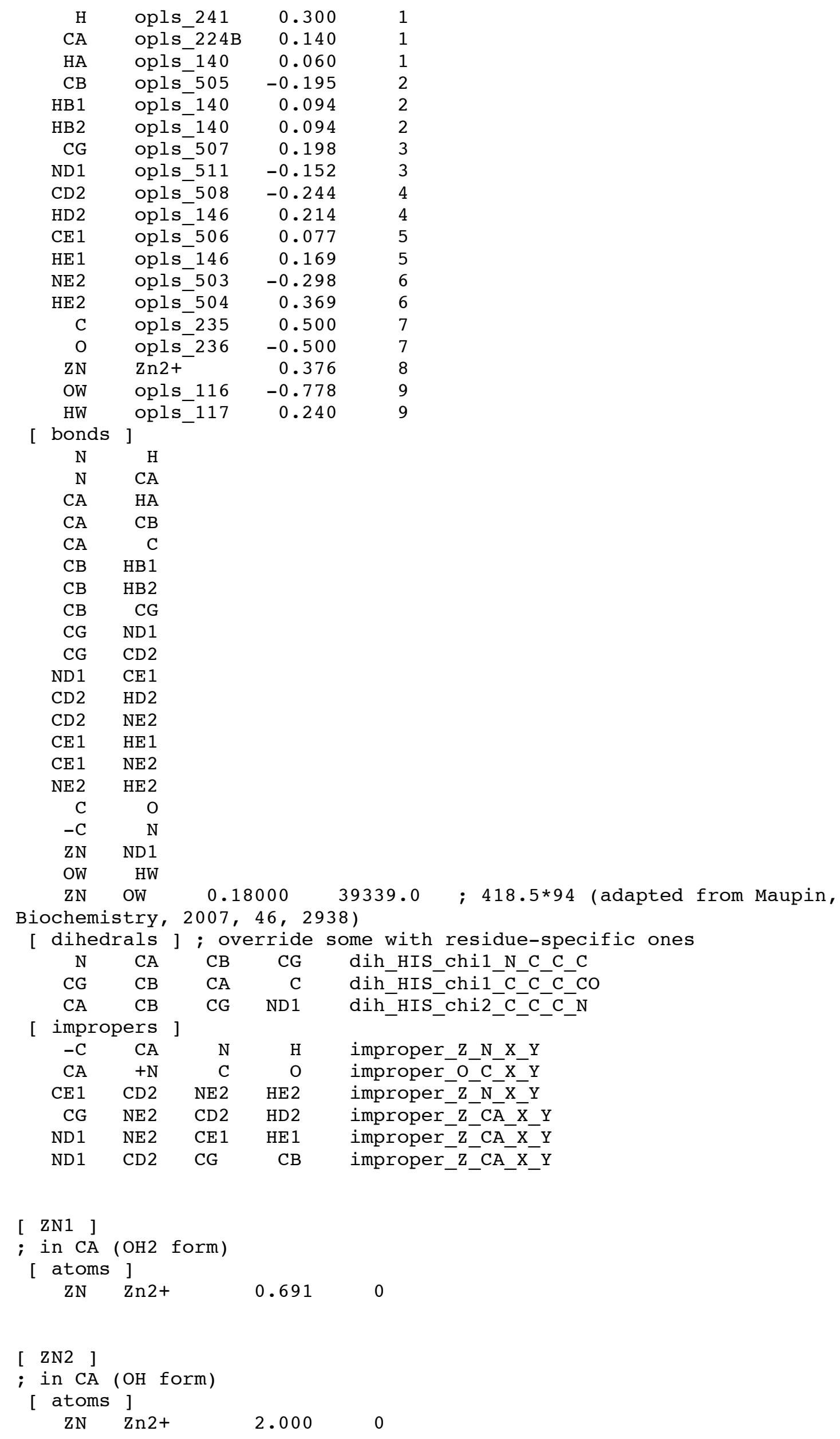


- aminoacids.hdb

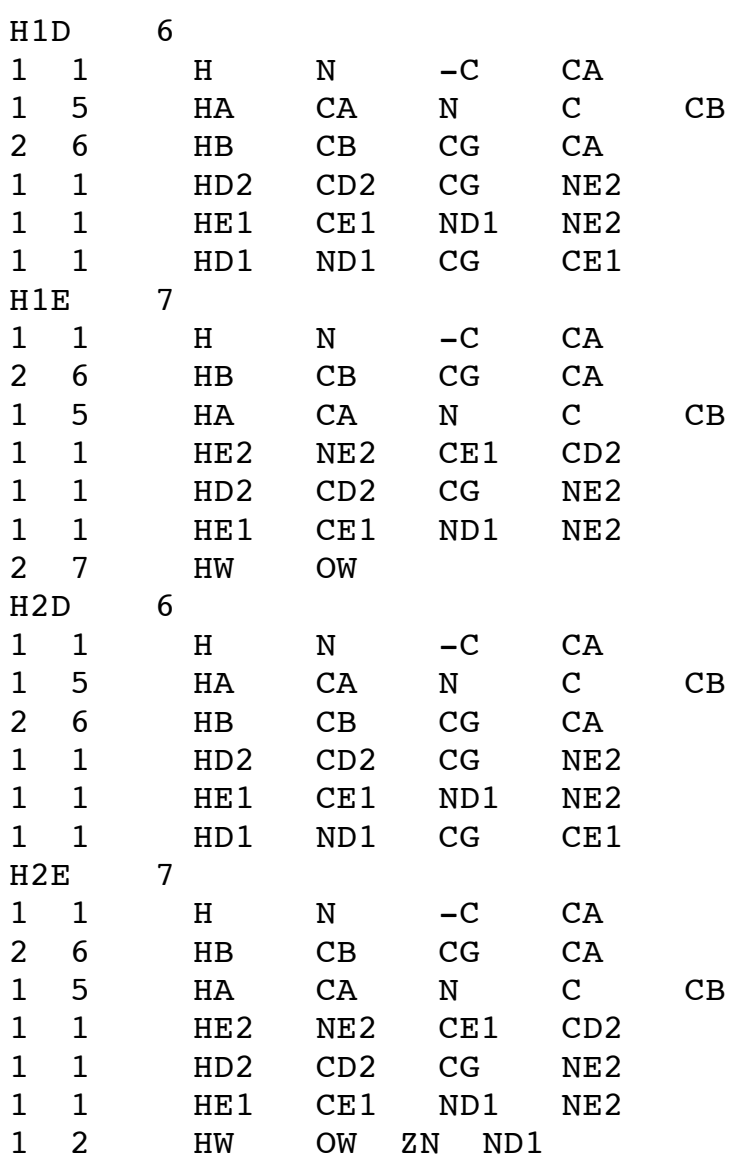

\section{- ffbonded.itp}

\section{[ bondtypes ]}

Zn2+ NB $\quad 1 \quad 0.20500 \quad 16740.0$; $418.5 * 40$ (adapted from Maupin,

Biochemistry, 2007, 46, 2938)

[ angletypes ]

Zn2+ NB $\quad$ CR $\quad 1126.000 \quad 83.700 ; 4.185 * 20$ (adapted from

Maupin, Biochemistry, 2007, 46, 2938)

Zn2+ NB $\quad$ CV 1126.000

Maupin, Biochemistry, 2007, 46, 2938)

$\mathrm{Zn} 2+\mathrm{NB} \quad \mathrm{CW} \quad 1 \quad 126.000$

Maupin, Biochemistry, 2007, 46, 2938)

$\begin{array}{llll}\text { NB } & \text { Zn2+ NB } & 1 & 109.500\end{array}$

Maupin, Biochemistry, 2007, 46, 2938)

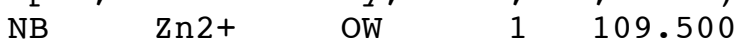

$\mathrm{Zn} 2+$ OW $\quad \mathrm{HW} \quad 1 \quad 124.000$

$83.700 ; 4.185 * 20$ (adapted from

Maupin, Biochemistry, 2007, 46, 2938)

$83.700 ; 4.185 * 20$ (adapted from

96.255 ; $4.185 * 23$ (adapted from

$418.500 \quad ; 4.185 * 100$

$83.700 ; 4.185 * 20$ (adapted from

[ dihedraltypes ]

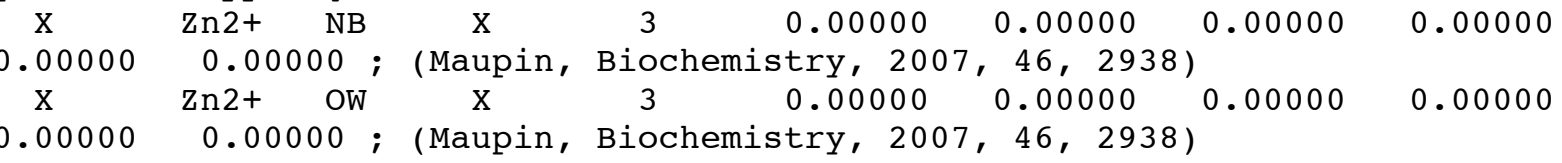

